\title{
NEW MODALITIES IN KNEE OSTEOARTHRITIS TREATMENT USING AUTOLOGOUS BONE MARROW-DERIVED MONONUCLEAR CELLS
}

\author{
Valdis Gončars ${ }^{1, \#}$, Konstantīns Kalnbērzs ${ }^{1}$, Ëriks Jākobsons ${ }^{2,3}$, leva Briede ${ }^{2}$, \\ Kristaps Blūms ${ }^{4}$, Kristaps Ërglis ${ }^{2}$, Mārtinš Ěrglis ${ }^{2}$, Liene Patetko², \\ Indrikis Muižnieks ${ }^{5}$, and Andrejs 'Ërglis ${ }^{2}$

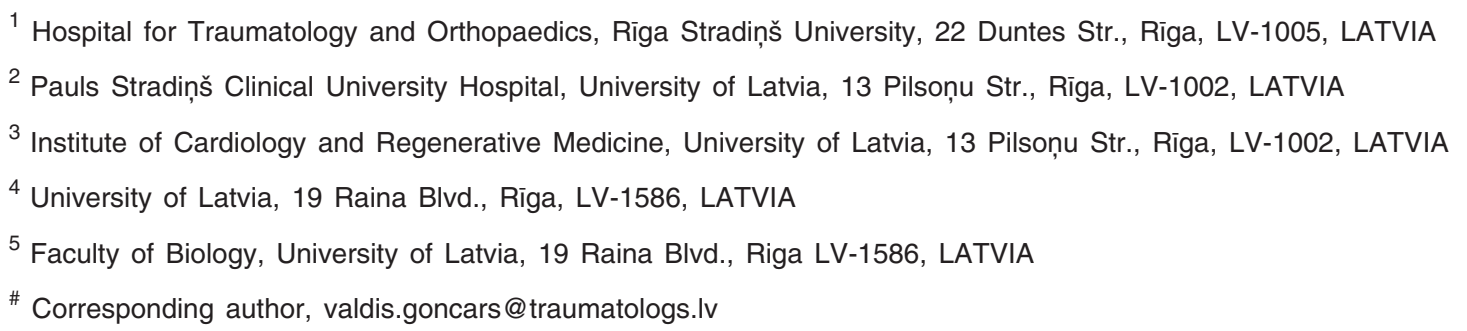 \\ Contributed by Andrejs Ërglis
}

\begin{abstract}
The clinical effects on knee osteoarthritis (OA) symptoms and tissue structure were evaluated after bone marrow-derived mononuclear cell intraarticular injection. A group of 32 patients with 34 knee joints in stage II-III osteoarthritis were treated by intraarticular injection of mononuclear cell suspension. Clinical results were obtained by KOOS (Knee Osteoarthritis Outcome Score) and KSS (Knee Society Score) scores during a 12 months follow-up period. Radiological evaluation was performed using magnetic resonance imaging. A comparison with a control group of 28 patients treated with routinely used three hyaluronic acid intra-articular injections was made. No adverse effects were observed after the bone marrow derived mononuclear cells (BM-MNC) injection. At the end point of the follow up all score results had improved, compared to those at to the starting point. $65 \%$ of patients maintained minimal perceptible clinical improvement of the score results. The Whole Organ Magnetic Resonance Imaging Score showed improvement from 44.31 to 42.93 points $(\mathrm{p}<0.05)$ during a 6-7 month period. Comparing score results to the control group, a statistically significant $(\mathrm{p}<0.05)$ improvement in the KOOS pain subscale score at the 6 and 12 months was observed in the mononuclear cell group. BM-MNC injection leads to a decrease of knee OA symptoms and slows changes in structure of the degenerative joint tissue.
\end{abstract}

Key words: knee osteoarthritis, mesenchymal stem cells, hyaluronic acid, bone marrow mononuclear cells, regenerative therapy.

\section{INTRODUCTION}

The treatment of early stages of the knee joint osteoarthritis continues to present challenges in orthopaedic practice. The ideal therapy should target both the inflammatory and the tissue degeneration processes in the joint building tissue, the combination of which characterises the development of osteoarthritis. Routinely per oral used nonsteroidal antiinflammatory drugs (NSAID) and corticosteroid injections successfully reduce inflammation; however, an effect on the degenerative process in joint structures, such as cartilage, the synovial membrane and the metaphyseal bone has not been demonstrated. Additionally, long-term use of NSAID therapy is commonly associated with gastrointestinal, he- patic, renal, and/or cardiac side effects amongst others, etc. (McAlindon et al., 2014)

Alternatives include viscosupplementation, a treatment that utilises hyaluronic acid (HA). It provides joint lubrication and shock absorbency, and acts as a backbone for the proteoglycans of the extracellular matrix (Kon et al., 2012). However, the evidence gathered from clinical trials does not clearly support any positive effects of HA on slowing down the progression of $\mathrm{OA}$, and the guidelines for the clinical use of the HA are not recommended unanimously, advising for a cautious employment of this treatment (Hunter, 2015; van Tiel et al., 2016). The limitations of the NSAID, corticosteroids and the HA have motivated further research 
into solutions that could provide clinical benefits of OA treatment. Recently, new biological treatments have been developed with platelet-rich plasma (PRP) (Filardo et al., 2015b, a) and mesenchymal stem cells (MSCs), to address cartilage lesions and the OA degeneration process. Stem cells represent naive cells that differentiate to specific tissue lineages during development. These cells reside within tissue compartments with a purpose to replace cell populations over the lifetime. In the 1970s, Freidenstein discovered that cells extracted from red bone marrow in vitro demonstrated properties of adherence, colony formation, and osteogenic lineage differentiation (Friedenstein, 1976). Later in the 1990s, Caplan named these cells mesenchymal stem cells (MSCs) and proposed that they would have a differentiation capacity for all mesenchymal tissues.(Caplan, 1991). So far this theory has not been sufficiently proven and the concept of the bone marrow derived cells as 'stem' cells remains open to debate. Later, Caplan revised the concept of multipotent stem cells and proposed that pericytes, the cells closely associated with capillaries and micro-vessels, are the main source of multipotent stem cells (Caplan, 2008). The International Society of Cell Therapy defined MSCs as plastic-adherent, capable of trilineage differentiation and possessing the cell surface antigens CD105, CD73, and CD90 with a lack of CD45, CD34, CD14, CD11b, CD79i, CD19, or HLA-DR. (Dominici et al., 2006) The attractiveness of the MSCs in cartilage repair can be found in their immunomodulatory capacity and trophic factor production. MSCs have immune properties to suppress immune cell proliferation and cytokine release (Chen et al., 2013). Despite the theoretical controversies, clinical studies that examine the use of the MSCs in treating chondral injury and OA, have demonstrated encouraging clinical outcomes, as well as the magnetic resonsnce imaging (MRI)) and histological findings, consistent with restoration of hyalinelike cartilage (Gobbi et al., 2014; Nakamura et al., 2014; Gobbi and Whyte, 2016). The renewal of joint building tissue and slowing down of degenerative processes caused by OA has been reported (Friedenstein et al., 1966; Caplan and Dennis, 2006). A uniform evaluation of clinical benefit of the BMSC-based therapy of larger patient groups is still missing.

The primary aim of this study was to determine the clinical effectiveness, and changes in pain and OA symptoms after a single intra-articular injection of bone marrow derived mononuclear cells (BM-MNC) on Kellgren Lawrence classification (K-L) grade II-III affected joints over a period of 12 months, in comparison with the clinical effectiveness of a patient group treated with hyaluronic acid injections. The secondary aims were to evaluate the joint building tissue structural changes over a 12 months follow-up period using $\mathrm{X}$-ray and magnetic resonance imaging methods, and to observe the presence of adverse events associated with applied therapy.

\section{MATERIALS AND METHODS}

The study employed a randomised controlled trail (RCT) with evidence level II. The study was conducted in the Lat- vian State Hospital for Traumatology and Orthopaedics and Cell Transplantation Centre at Pauls Stradiņš Clinical University during 2012-2016.

The inclusion criteria were: degenerative osteoarthritis of the knee, K-L grade II-III, at least 6 months of persisting pain and some of OA symptoms. The exclusion criteria were: age 75 years, oncologic diseases, severe kidney, lung or liver function disorder, haematologic diseases including anaemia and thrombocytopenia, first-type diabetes mellitus, severe effusion, contracture or instability and axial deformities more than 10 degrees in the knee joint, septic arthritis or skin disorders, use of corticosteroids and immunosuppressive agents, previous injection in target knee within two months. Before the inclusion, the clinical history, physical examination, routine laboratory tests, calibrated X-ray and MRI were performed. The previous medical history of the enrolled patients was carefully evaluated. The injection was performed not prior to 1 month after the surgical intervention in the same knee joint.

The clinical study protocol was approved by the State Central Medical Ethics Committee. All patients provided informed consents for the study according to the Helsinki Declaration and all patients voluntarily agreed to participate and signed informed consent forms.

Patients in the control group received in total three Na hyaluronate (HA) intra-articular injections with an interval of one week, starting at week 1 and finishing at week 3 . A GO-ON $25 \mathrm{mg} / 2.5 \mathrm{ml}$ pre-filled syringe containing Na hyaluronate $1 \%$ gel, average molecular weight $800-1500 \mathrm{kD}$, was used.

Bone marrow harvesting and cell preparation. Cells used in this study were extracted from the patient's own red bone marrow. Iliac crest puncture was performed under local anaesthesia. A total of up to $45 \mathrm{ml}$ of bone marrow was aspirated into heparin-treated syringes. The bone marrow aspirate was shipped at room temperature to the central cell-processing laboratory. The bone marrow aspirate was processed according to Good Manufacturing Practice standard (GMP) requirements. The bone marrow mononuclear cells (BM-MNCs) were isolated and enriched by density gradient centrifugation by Ficoll-Paque Premium (GE Healthcare Ltd.). Mononuclear cell fraction separation was performed at $800 \mathrm{~g}$ for $25 \mathrm{~min}$. The $\mathrm{MNC}$ fraction was washed three times with $45 \mathrm{ml} 0.9 \% \mathrm{NaCl}$ containing 10 $\mathrm{U} / \mathrm{ml}$ heparin and re-suspended in saline with $10000 \mathrm{U} / \mathrm{L}$ heparin. This isolation produced up to 5cc MNC suspension. During the gradient centrifugation, plasma factors, red blood cells and platelets where removed. The cell suspension used for injection contained only the mononuclear cell fraction and no other additional biological substances were added.

Flow cytometry was used to determine the MNCs count and cell viability in the cell material released for application. Samples of the final product were taken and used for flow cytometric analysis within $2 \mathrm{~h}$ after processing. Measure- 
ments with less than 50000 events were excluded from the cell count analysis.

Follow-up and BM-MNC injection procedure. Knee joint puncture without using local anaesthesia was performed. To be sure of correct needle placement in the joint cavity, 5 to $10 \mathrm{ml}$ of saline was injected. In case of free drainage of the saline by aspiration, correct placement in the knee joint cavity was conducted. The mononuclear cell suspension injection into the knee joint was performed without changing the needle position. After 1 hour of bed rest, patients were released home. No restrictions on further activities were given. The short term use of pain reliever drugs during the evaluation period of 12 months was accepted. The patients maintained previous habit of SYSODOA drug use and physical activity level. Regarding the physical activity at enrolment, patients were given recommendations to avoid excessive physical activity and sport exercises exceeding their normal everyday activities and habits. Evaluations were made on visits of patients at 1, 3, 6 and 12 months.

Clinical assessment. The clinical assessment was based on outpatient visits. Pain, changes in OA symptoms and knee joint function after physical examinations were assessed using the Knee Society Score (KSS). This scoring system is the version of the knee score modified by Dr. John Insall in 1993. The scoring system combines a relatively objective Knee Score that is based on clinical parameters and a Functional Score based on how the patient perceives his knee functions during specific activities. The maximum Knee Score is 100 points and the maximum Functional Score is 100 points (Insall et al., 1989). At the same time, patients completed the Knee Osteoarthritis Outcome Score (KOOS) test. KOOS consists of five subscales: pain, symptoms, and activities of daily living (ADL), sport and the recreation function (Sport/Rec), and the knee-related quality of life (QOL). A KOOS score of 100 indicates no symptoms and 0 indicates extreme symptoms (Roos et al., 1998). Scoring was done on the day of the procedure and 1, 3, 6 and 12 months after BM MNC injection.

Radiological assessment. Weight-bearing anteroposterior and lateral semi flexed radiographs were obtained before the cell injection procedure and 12 months later. Radiographs were scored according to the $\mathrm{K}-\mathrm{L}$ classification. Patients with grade 2 and 3 were enrolled for the study.

The MRI was performed only on the study group prior to and 6 to 7 months after BM MNC injection. The MRI examinations were performed with a $1.5 \mathrm{~T}$ scanner, using a dedicated knee coil. All patients were placed in the supine position. The MRI protocol included PD Fat Sat sequence on the sagittal, coronal, and axial planes, and PD FSE on the sagittal and coronal planes,

All X-rays and MRI images were evaluated by a musculoskeletal radiologist from another institution. The examiner was blinded to all clinical data. The MRI evaluation was performed using the semi-quantitative whole organ MRI scoring (WORMS) method. The WORMS score allows to
Table 1

MAXIMUM SCORES ATTAINABLE WITH WORMS

\begin{tabular}{lcccccc}
\hline & MFTJ & LFTJ & PFJ & S Region & Total \\
\hline Cartilage & 30 & 30 & 24 & & 84 \\
Marrow abnormality & 15 & 15 & 12 & 3 & 45 \\
Bone cysts & 15 & 15 & 12 & 3 & 45 \\
Bone attrition & 15 & 15 & 12 & & 42 \\
Osteophytes & 35 & 35 & 28 & & 98 \\
Compartment total & 110 & 110 & 88 & & \\
Menisci & 6 & 6 & & & 3 \\
Ligaments & & & & & 332 \\
Synovitis & & & & & 3 \\
Total & & & &
\end{tabular}

WORMS, Whole-organ Magnetic Resonance Imaging Score; MFTJ, medial tibiofemoral joint compartment; LFTJ, lateral tibiofemoral joint compartment; PFJ, patellofemoral joint compartment; S Region, subspinous non-articulating joint compartment

analyse 14 different features: articular cartilage integrity, subarticular bone marrow abnormality, subarticular cysts, subarticular bone attrition, marginal osteophytes, medial and lateral meniscal integrity, anterior and posterior cruciate ligament integrity, medial and lateral collateral ligament integrity, synovitis/effusion, intraarticular loose bodies, and periarticular cysts/bursitis. These features were evaluated and scored (Table 1) in 15 different regions subdivided by anatomical landmarks in the fully extended knee (Peterfy et al., 2004).

Statistical analysis. All data were analysed using IBM SPSS 22.0 software. Firstly, data were analysed for normality using skewness and kurtosis as well as a histogram and a Q-Q plot. If the data were normally distributed, then a paired or independent Student's t-test was performed. Paired t-tests were made to compare KSS, OKS, and KOOS subscales between the baseline and follow-up times within each group. A $p$-value 0.05 was considered as statistically significant. The Levene's test was used to evaluate homogeneity between the two study groups. An independent Student's t-test was used to compare the BMSC and HA groups. If data were not normally distributed, then the Mann-Whitney U test was used.

\section{RESULTS}

Seventy-two KL stage II-III knee OA patients were screened, of whom 56 were included in the study according inclusion and exclusion criteria (Fig.1). The patients were randomly divided into two groups: a bone marrow-derived mononuclear cells (BM-MNC) group and a hyaluronic acid (HA) as a control group. The patient randomisation process is presented in Figure 1.

After the comparison of clinical results between both groups, the study group was extended to 32 patients according to the same inclusion and exclusion criteria. The mean age of the new study group was $53.96 \pm$ SD14.15 years, 


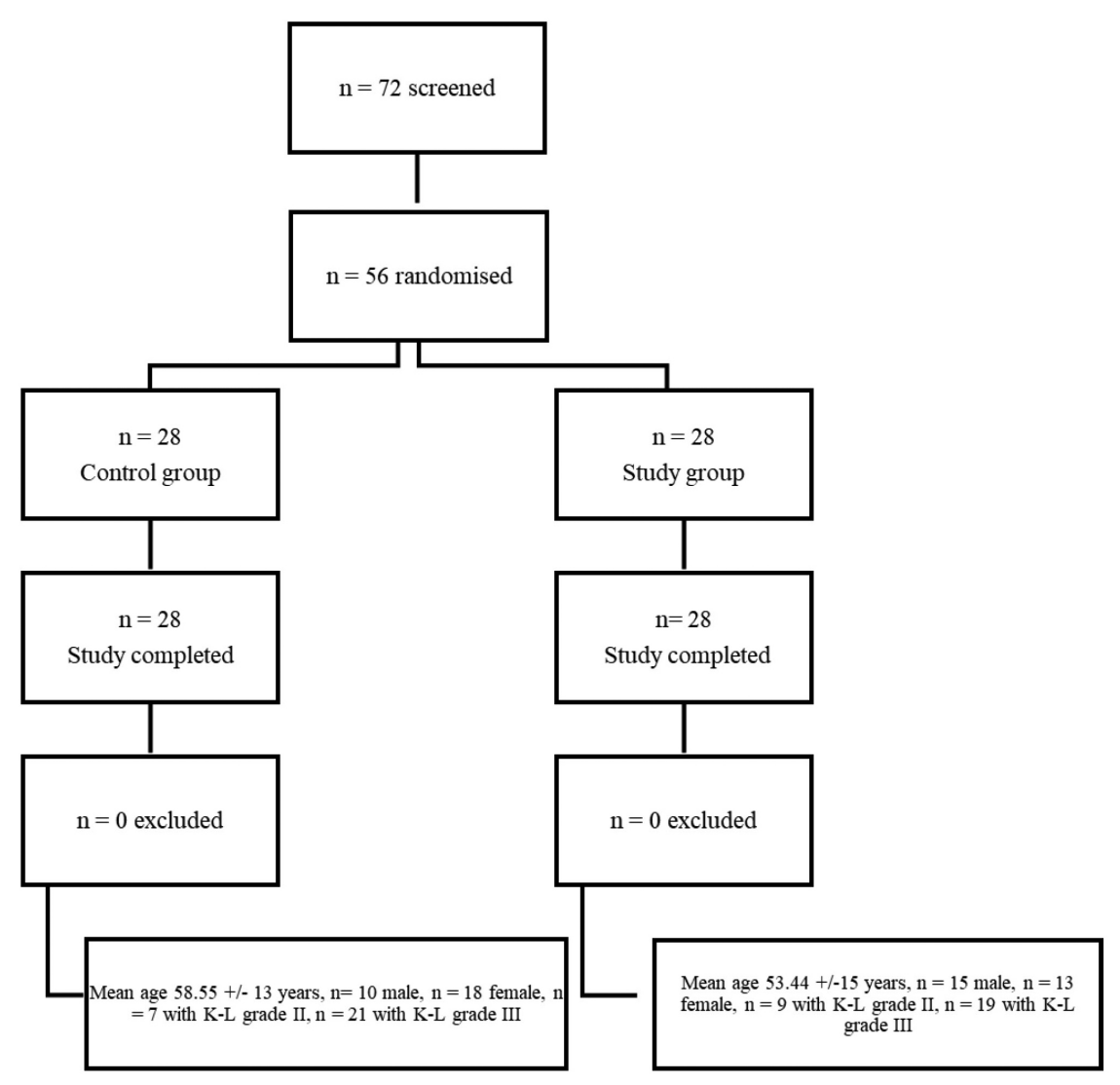

Fig. 1. The participation status of the study subjects phase I. male 16 , female 16 . Two of 32 patients received MNC injections in both knee joints. Based on previous medical history, total knee arthroplasty on the contra lateral knee joint was performed on ten patients, and total hip replacement in one patient case. Arthroscopy with meniscus resection on the same knee joint was performed on 11 patients and in one case an ACL replacement had been previously done. The two youngest patients of the cohort had a previous history of patellar dislocations.

No adverse effects after the BM-MNC injection were observed. The patients reported the procedure of the iliac crest puncture as painless and no complications in donor sites were observed. The knee joint pain and swelling caused by the puncture and the BM-MNC injection declined during the first 24 hours in the majority of patients. No additional treatment was applied. A positive response was observed in patients for $97 \%$ of knees after the BM-MNC injection. At the end point of the follow up all subscale results had improved, compared to those at the starting point. The KOOS total score improved by +15.3 points, the symptoms subscale by +9.3 , the pain subscale by +20.5 points, the activity and the daily living subscale by +18.4 , the sports subscale by +18.5 and the quality of life subscale by +23.9 points. Table 2 KOOS score results during the follow-up period.

A statistical analysis of the KOOS score results in all subscales between the starting point and the follow-up times demonstrated statistically significant improvement $(p<$ 0.05 ) on all subscales, except on symptoms subscale at time 12 months and the sport subscale at 1 month after the BM $\mathrm{MNC}$ injection.

During the first months after the BM-MNC injection, the biggest improvement was observed in the pain, and activity of the daily living subscales; however, the results in the sport and the quality of life subscales improved more progressively during the 12-month period.

KOOS SCORE RESULTS DURING THE FOLLOW-UP PERIOD

\begin{tabular}{|c|c|c|c|c|c|c|c|}
\hline Time point & & Symptom & Pain & $\begin{array}{l}\text { Activity of daily } \\
\text { living }\end{array}$ & Sport & Quality of life & Total \\
\hline beginning & Mean \pm SD & $60.8 \pm 20,1$ & $60.2 \pm 19.0$ & $66.9 \pm 20.3$ & $43.7 \pm 24.8$ & $35.1 \pm 20.0$ & $61.6 \pm 15.0$ \\
\hline 1st month & Mean \pm SD & $77.0 \pm 16.6$ & $84.3 \pm 10.1$ & $87.9 \pm 10.3$ & $57.4 \pm 18.3$ & $52.4 \pm 22.7$ & $71.3 \pm 15.1$ \\
\hline 3rd month & Mean \pm SD & $75.5 \pm 18.3$ & $80.1 \pm 16.7$ & $83.6 \pm 16.2$ & $68.7 \pm 22.4$ & $57.3 \pm 23.4$ & $78.3 \pm 16.0$ \\
\hline 6th month & Mean \pm SD & $72.2 \pm 19.8$ & $81.5 \pm 16.2$ & $84.7 \pm 15.2$ & $67.3 \pm 19.8$ & $50.9 \pm 22.7$ & $78.7 \pm 12.2$ \\
\hline 12th month & Mean \pm SD & $70.1 \pm 19.7$ & $80.7 \pm 16.8$ & $85.0 \pm 14.1$ & $65.2 \pm 18.7$ & $59.0 \pm 18.9$ & $76.9 \pm 13.3$ \\
\hline
\end{tabular}

KOOS, Knee Osteoarthritis Outcome Score 


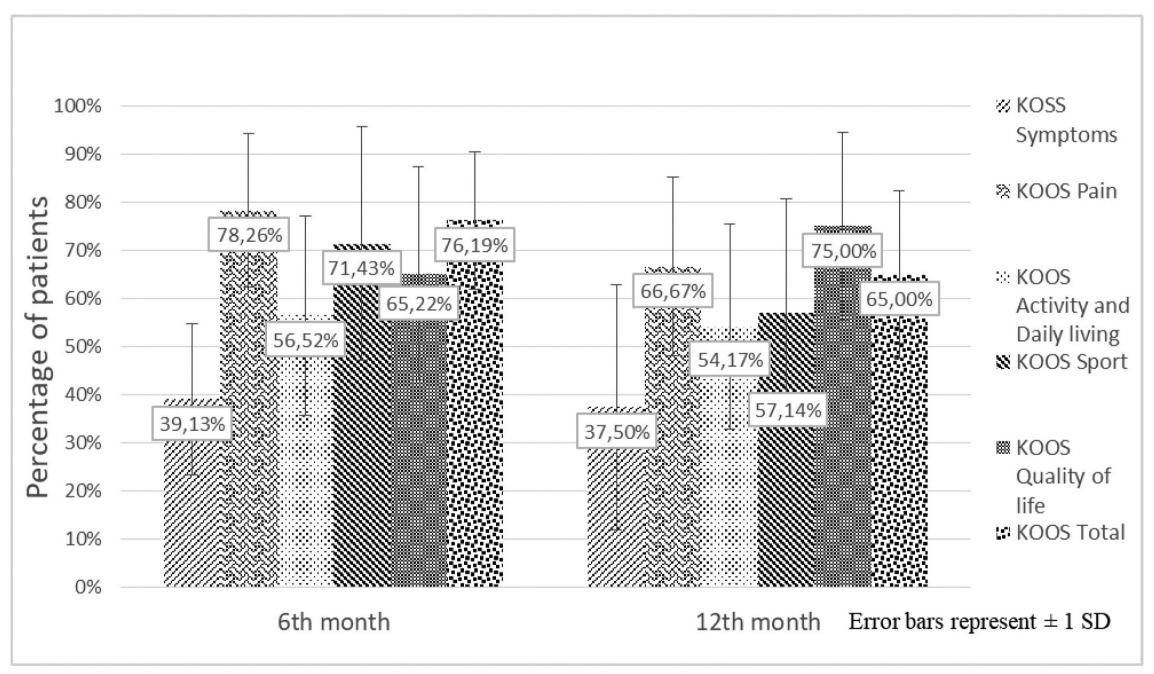

Fig. 2. Minimal perceptible clinical improvement of 10 points by KOOS score

Table 3

KSS SCORE RESULTS DURING THE FOLLOW UP PERIOD

\begin{tabular}{lc|c|c|c}
\hline & KSS score results & KSS knee score & $p$ & KSS Function \\
\hline beginning & Mean \pm SD & $60.25 \pm 18.52 \%$ & & $62.55 \pm 22.81 \%$ \\
1st month & Mean \pm SD & $80.81 \pm 13.37 \%$ & 0.00006 & $79.91 \pm 19.40 \%$ \\
3rd month & Mean \pm SD & $80.41 \pm 15,84 \%$ & 0.00024 & $87.44 \pm 16.65 \%$ \\
6th month & Mean \pm SD & $80.39 \pm 18.24 \%$ & 0.00017 & $87.68 \pm 14.75 \%$ \\
12th month & Mean \pm SD & $81.70 \pm 18.56 \%$ & 0.0024 & 8.00002 \\
\end{tabular}

KSS, Knee Society Score

The clinically relevant changes of symptoms or minimal perceptible clinical improvement measured with the KOOS score begin at a threshold of 8-10 point difference (Roos and Lohmander, 2003).

After 12 months, $65 \%$ of patients still showed improvement of more than 10 points of the KOOS total score. After 6 months, $78.26 \%$ of patients showed improvement in the pain subscale by more than 10 points, compared to $66.67 \%$ of patients after 12 months. However the proportion of patients with more than 10-point improvement of the quality of life subscale increased from $65.22 \%$ after 6 months to 75\% after 12 months (Fig. 2).

Figure 2 shows the proportion of patients that reached a 10-point improvement level during the follow up period.

The OA clinical signs measured with KSS demonstrated improvement in both the knee score and the function score subscales (Table 3). After 12 months, the KSS knee score showed +21.45 and the function subscale +27.08 points improvement (Table 3).

The KSS knee score subscale demonstrated a similar pattern as compared to the KOOS score. The KSS knee score that evaluated pain and symptoms demonstrated improvement particularly during the first month whereas the functions score improved more progressively.

Results of radiological investigation. The X-rays showed no signs of further development of $\mathrm{OA}$ and no changes in the $\mathrm{K}-\mathrm{L}$ grade 12 months after the BM-MNC injection.
Table 4

WORMS SUBSCALE RESULTS

\begin{tabular}{l|c|c|c}
\hline & Cartilage results & $\begin{array}{c}\text { Bone marrow } \\
\text { abnormality results }\end{array}$ & Synovitis results \\
\hline Before & $17.69 \pm 14.61$ & $1.58 \pm 2.579$ & $1.24 \pm 0.7$ \\
After & $17.13 \pm 14.71$ & $0.97 \pm 1.94$ & $0.67 \pm 0.86$ \\
$p<0.05$ & & &
\end{tabular}

WORMS, Whole-organ Magnetic Resonance Imaging Score

Non-expected changes in bone structure or any periosteal reaction were not evident.

MRI was performed on 30 of 34 study group patients. Unfortunately, four patients refused to undergo the final MRI due to different reasons. The MRI was evaluated using the WORMS score. The mean score before the injection was 44.31 points and after 6 months, a significant $(p<0.05)$ improvement to 42.93 points was observed. We found changes on three of WORMS score features: articular cartilage, subarticular bone marrow and synovitis (Table 4). In all other WORMS score features changes during the follow up period was not observed.

Further analysis of the WORMS bone marrow abnormalities section demonstrated a decrease of bone marrow oedema in $57.14 \%$ of patients after 6 months, where $28.57 \%$ did not change, but in $14.29 \%$ worsening was observed. Cartilage changes on the MRI after 6 months improved in $37.93 \%$, no change was observed in $55.17 \%$ and further de- 


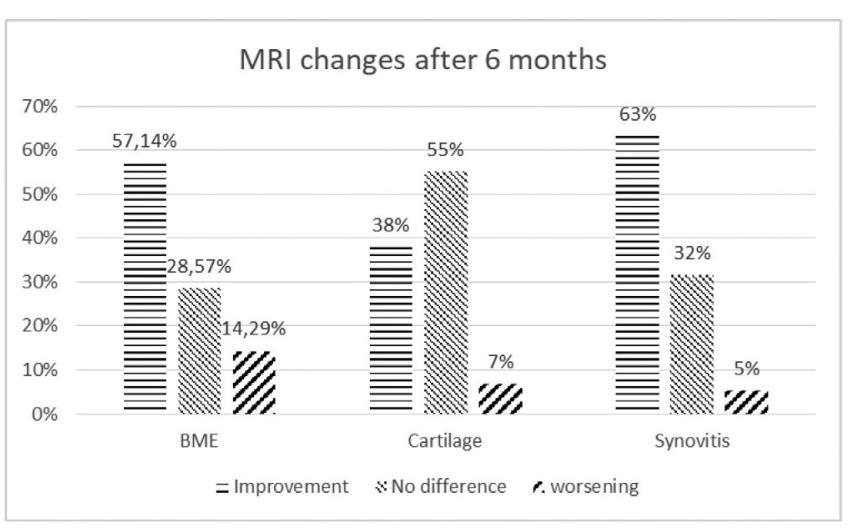

Fig. 3. Cartilage changes on the MRI after 6 months.

generation was present in $6.90 \%$ of cases. The MRI changes related to the synovitis improved in $63.16 \%$ of cases, no difference in $31.58 \%$ and increased in $5.26 \%$ of cases (Fig. 3).

In a clinical case of a 62-year-old woman with K-L stage III OA, MR scans (Fig. 4a; b) demonstrated patellar cartilage defect according to WORMS 3. MR scans 7 months after BM-MNC injection are shown in Fig. $4 \mathrm{c}$; d Cartilage restoration to WORMS 0 was observed. The KOOS total after 12 months improved by $+28 \mathrm{p}$.

In a clinical case of a 56-year-old woman with K-L stage III OA, a MR scan (Fig. 4e) demonstrated BMO of tibia according to WORMS 3 and synovitis 3. MR scans 6 months after BM-MNC injection are shown in Fig. 4f. Bone marrow edema reduced to WORMS 0 and synovitis to WORMS 1 . The KOOS total after 12 months improved by $+25 \mathrm{p}$.

Cell material analysis. Before the injection, flow cytometry tests were applied to each extracted mononuclear cell sample. The mononuclear, the CD34+ population count and cell viability were determined. From 34 cell processing runs, 24 flow cytometry tests were analysed, and 10 were excluded according to the protocol, as the measurement did not reach 50000 events. The average final yield of cell extraction was $45.56 \cdot 10^{6} \pm 34.94 \cdot 10^{6}$ MNC containing $1.04 \cdot 10^{6} \pm 1.61 \cdot 10^{6} \mathrm{CD} 34+$ cells. The cell viability was determined prior to the cell extraction process in the red bone marrow and after the final cell preparation. The average cell viability in the red bone marrow was $74.36 \pm 9.85 \%$, but after the preparation processes the viability increased to 79.75 $\pm 11.28 \%$.

No positive correlation between the used cell quantity and the OA clinical signs of improvement was found.

The comparison of BM MNC and HA groups. The clinical results of randomised 28 patients of the mononuclear cell and hyaluronic acid groups were compared based on the score results, 12 months after the first injection (Table 5). All results in the BM MNC group were superior to the HA group except on the KOOS symptom subscale.

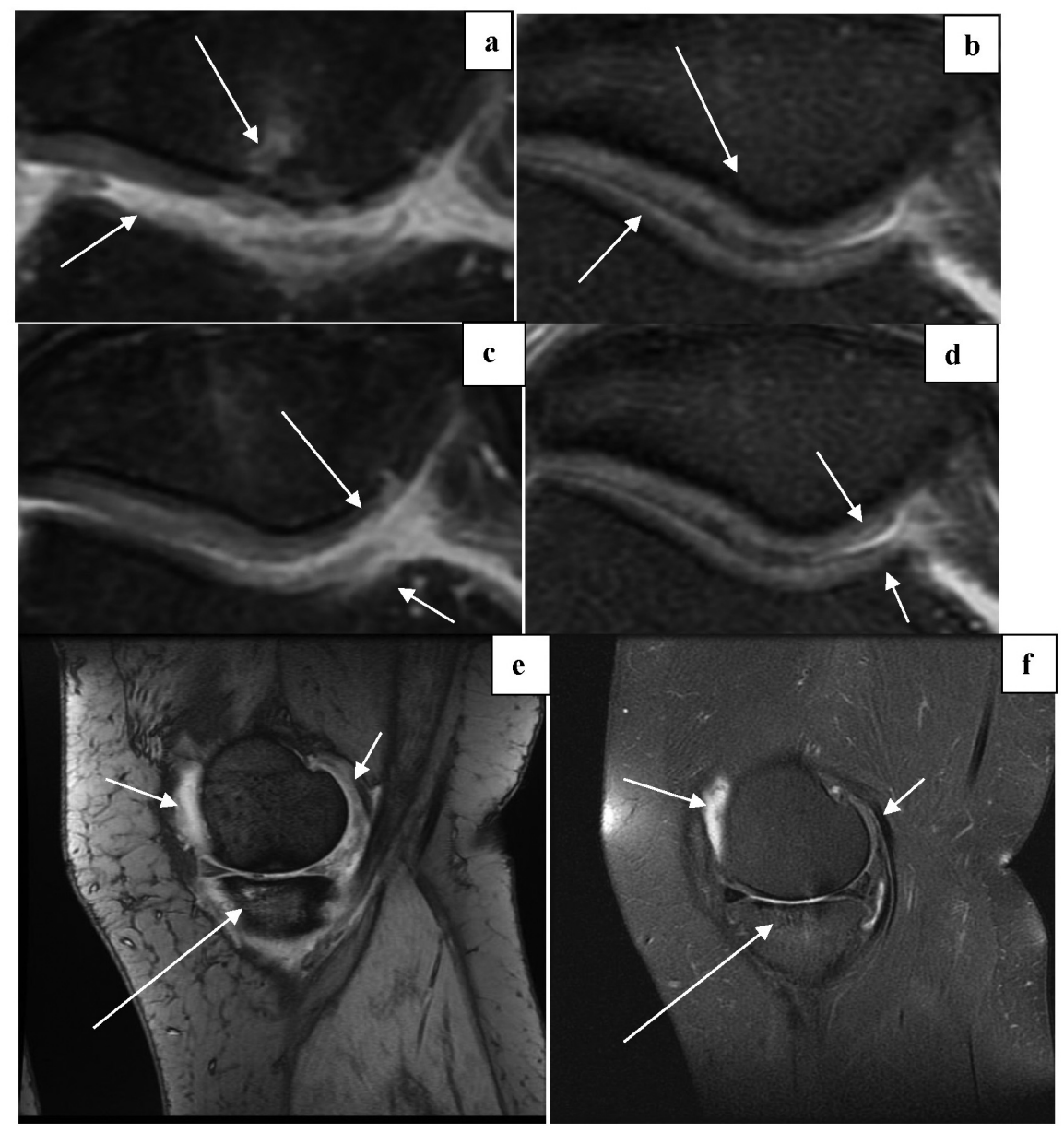

Fig. 4. MR scans of a 62-year-old woman with K-L stage III OA: a, before bone marrow derived mononuclear cells (BM MNC) injection, cartilage defect Whole-organ Magnetic Resonance Imaging Score (WORMS) 3 on patella and femur lateral surface; $\mathbf{b}$, before BM MNC injection, cartilage defect WORMS 3 on patella and femur medial surface; c, seven months after BM MNC injection, cartilage restoration to WORMS 0 ; d, seven months BM MNC injection, cartilage restoration to WORMS 1 on medial patella surface and WORMS 0 to medial femur surface; $\mathbf{e}$, before BM MNC injection, BMO WORMS 3 and synovitis 3; f, six months after BM MNC injection, BMO WORMS 0 and synovitis WORMS1 


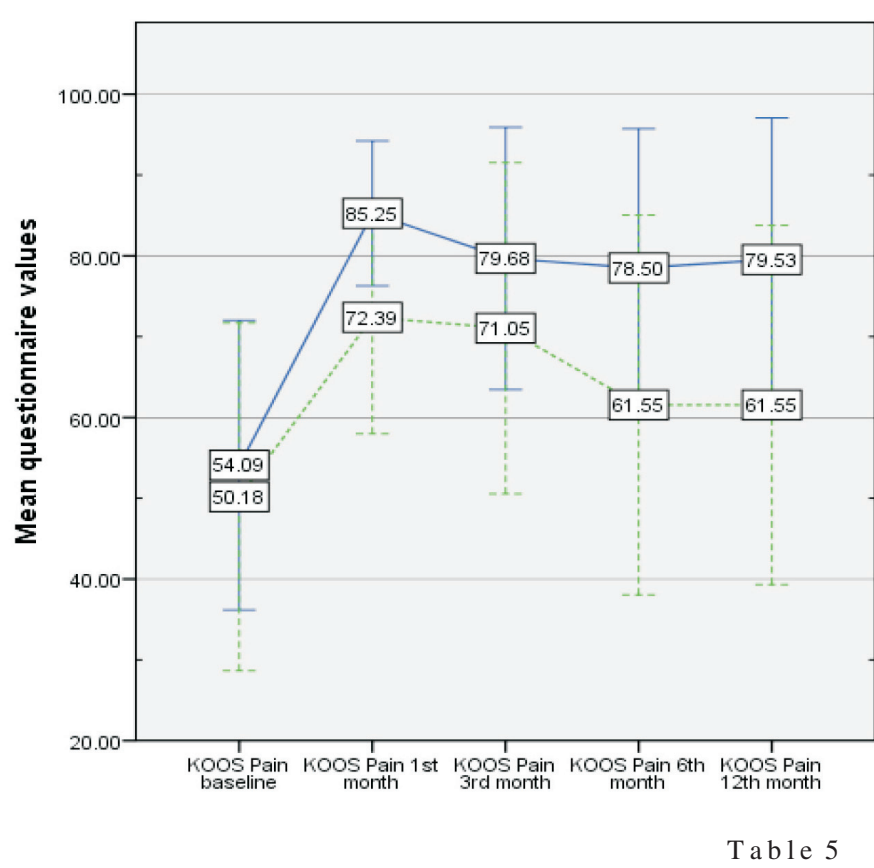

SUBSCALE MEAN VALUE CHANGES BEFORE TO 12 MONTHS AFTER THERAPY

\begin{tabular}{lcc}
\hline \multicolumn{1}{c}{ Score subscales } & BM MNC group & HA group \\
\hline KOOS Symptoms & 5.07 & $12.62^{*}$ \\
KOOS Pain & $25.44^{*}$ & $11.37^{*}$ \\
KOOS Activity of daily living & $21.36^{*}$ & $19.09^{*}$ \\
KOOS Sport & 19.00 & 5.97 \\
KOOS Quality of life & $28.83^{*}$ & $18.90^{*}$ \\
KOOS Total & $18.25^{*}$ & $12.59^{*}$ \\
KSS Knee score & $25.42^{*}$ & $10.73^{*}$ \\
KSS Function & $38.32^{*}$ & $17.5^{*}$ \\
& \multicolumn{2}{|c}{$p<0.05$}
\end{tabular}

KOOS, knee osteoarthritis outcome score; BM MNC, bone marrow derived mononuclear cells; HA, hyaluronic acid

The bigest difference between the BM-MNC and the HA groups was found on the KOOS pain subscale. The BM-MNC group showed significant $(p<0.05)$ superiority over the HA group, 6 and 12 months after injection (Fig. 5). In all other score subscales the score result differences lacked statistical significance (Fig. 5).

\section{DISCUSSION}

Clinical studies about the use of the BMSC in the treatment of isolated cartilage lesions and the OA patients have reported a clinical benefit in most of the studies, regardless of the cell source, indication, or the administration method, with better results in patient groups of younger age, a lower BMI, a smaller lesion size, and earlier stages of OA. (Gupta et al., 2012; Jo et al., 2014). No major adverse events, strictly related to the treatment, have been reported (Filardo et al., 2016).

\author{
Treatment \\ I BM-MNC \\ I $\mathrm{HA}$ \\ Error Bars: +/- $1 \mathrm{SD}$
}

Fig. 5. Knee osteoarthritis outcome score pain results comparison between BM-MNC and hyaluronic acid groups.

Our results clearly demonstrate pain relief in the majority of cases without any serious side effects. Stiffness and other OA symptoms had not changed significantly. However, correlation of improvement with age or OA K-L stage was not evident in our patient group. Some studies demonstrated decrease of both knee pain and functions improvement using bone marrow aspirate concentrate (BMAC) injection, pure and augmented with PRP and adipose tissue in the knee OA treatment (Centeno et al., 2014; Kim et al., 2014). However, more adverse effects like knee pain and swelling in the BMAC and the BMAC combined with adipose tissue groups were reported. In our patient group treated with the BM MNC, adverse effects were not observed. We applied the autologous bone marrow derived mononuclear cell fraction containing a variety of different progenitor cell populations and an enriched MSC cell population. The bone marrow aspirate was processed in order to isolate mononuclear cells and reduce contamination with red blood cells and erythrocyte lysate. We assume that purification of the cell solution is the reason why the adverse effects like swelling and pain after the cell injection were not observed.

The cell yields and correlation to clinical effects are active topics for discussion in all fields using the MSCs as a therapeutic agent. There is no clear answer so far. We observed a wide range of cell yields $(8.3 \times 106$ to $158.79 \times 106)$. The extracted mononuclear cell yield might be dependent on the patient's individual condition or the bone marrow acquisition and the cell processing quality. A previous study of the BM-MNC processing efficacy found a similar variety of mononuclear cell quantity (Jakobsons, 2013). The correlation between the used mononuclear cell quantity and the clinical improvement was calculated. Surprisingly no correlation during 12 months was evident. A larger sample group and a wider range between the used cell quantities could be helpful to determine the optimal cell dosage patterns to achieve the best clinical results. Comparing the clinical 
effect measured with the KOOS score, the obtained improvement levels were similar to those reported previously (Oliver et al., 2015). Approximately 10-point higher improvement levels were reported by Kim et al (2014). Both teams used BMAC and lipoaspirate combination injected in the OA affected knee joints (Oliver et al., 2015).

The assessment of scores of our patient group showed significant reduction of pain starting with the first month post procedure and lasting during the 12 month follow-up period. A maximum of beneficial effects such as pain, OA symptoms, the activity of daily living, were reached at the first month post procedure and continued at the same level or slightly decreased during the 12 months of the follow up period. Despite that, the quality of life improved continuously and reached a maximum at month 12 . The highest improvement was regarding knee pain. The least improvement was observed in other OA symptoms like stiffness or crepitation in the joint.

In a study using adipose derived cultured MSCs on knee OA patients, MRI using the WORMS score significantly improved from 60.0 points to 48.3 points $(p<0.001)$, and a particularly notable change was observed in the cartilage whole-organ MRI score, which improved from 28.3 points to 21.7 points $(p<0.001)$ (Koh et al., 2013).

Our MRI findings also demonstrated an improvement of score and a significant reduction of synovial effusion and bone marrow oedema. Cartilage surface restoration was observed in some individuals, but was not clearly evident in the majority of cases. Bone marrow oedema usually is associated with pain and activity of degenerative processes (Lee et al., 2015). The loss of bone marrow integrity will compromise repair and regeneration and foster degeneration in the joint cartilage. However a natural history of OA signs detected on MRI could be taken in account. Lack of MRI investigation of the control group requires us to be careful to draw conclusions about the regenerative effect of the applied therapy. After assessing all findings, we can conclude that the slowdowns of degenerative changes in some individuals after the BM MNC injection were evident.

Limitations. The placebo effect might play a role in the patients' subjective self-scoring process, as we did not use a blinded study. Some of the differences measured with scores were not statistically significant because of high variability of results. There was no control group for evaluation of the MRI results. Therefore, conclusions about tissue structural changes cannot be presented with the highest level of evidence strength. A larger sample size and a longer follow-up period will be necessary to improve reliability of the data and will be helpful to determine correlations of the factors considered on outcome.

\section{CONCLUSIONS}

Intra-articular injection of BM MNC is a safe manipulation with no side effects over a 12-month period.
A single dose injection of BM MNC reduces knee stage II-III osteoarthritis symptoms and might decrease degenerative changes in the joint tissue.

Mononuclear cells in knee osteoarthritis treatment is characterised by better pain relief in the long-term period, comparing to hyaluronic acid treatment.

\section{ACKNOWLEDGEMENTS}

The Pauls Stradiņš Clinical University Hospital, University of Latvia, Research Institute of Cardiology, Latvian State Hospital for Traumatology and Orthopaedics is acknowledged for institutional support.

The authors declare that there is no conflict of interest.

\section{REFERENCES}

Caplan, A. I. (1991). Mesenchymal stem cells. J. Orthop. Res., 9 (5), 641-650.

Caplan, A. I. (2008). All MSCs are pericytes? Cell Stem Cell, 3 (3), 229-230.

Caplan, A. I., Dennis, J. E. (2006). Mesenchymal stem cells as trophic mediators. J. Cell. Biochem., 98 (5), 1076-1084.

Centeno, C., Pitts, J., Al-Sayegh, H., Freeman, M., Centeno, C., Pitts, J., Al-Sayegh, H., Freeman, M. (2014). Efficacy of autologous bone marrow concentrate for knee osteoarthritis with and without adipose graft. BioMed Res. Int., DOI:10.1155/2014/370621.

Chen, W. C. W., Park, T. S., Murray, I. R., Zimmerlin, L., Lazzari, L., Huard, J., Péault, B. (2013). Cellular kinetics of perivascular MSC precursors. Stem Cells Int., DOI:10.1155/2013/983059.

Dominici, M., Le Blanc, K., Mueller, I., Slaper-Cortenbach, I., Marini, F., Krause, D., Deans, R., Keating, A., Prockop, D., Horwitz, E. (2006). Minimal criteria for defining multipotent mesenchymal stromal cells. Cytotherapy, 8 (4), 315-317.

Jakobsons, E., Cakstina, I., Ramata-Stunda, A., Vorobjeva, V., Biluna, L., Boroduskis, M., Erglis, K., Narbute, I., Jegere, S., Erglis, A. (2013). Bone marrow mononuclear cell separation yield in myocardium infarction, coronary disease and type 2 diabetes and dilated cardiomyopathy patient groups. Cytotherapy, 15 (4), S31.

Filardo, G., Di Matteo, B., Di Martino, A., Merli, M. L., Cenacchi, A., Fornasari, P., Marcacci, M., Kon, E. (2015a). Platelet-rich plasma intra-articular knee injections show no superiority versus viscosupplementation: A randomized controlled trial. Amer. J. Sports Med., 43 (7), 1575-1582.

Filardo, G., Kon, E., Roffi, A., Matteo, B. D., Merli, M. L., Marcacci, M. (2015b). Platelet-rich plasma: Why intra-articular? A systematic review of preclinical studies and clinical evidence on PRP for joint degeneration. Knee Surg. Sports Traumatol. Arthrosc., 23 (9), 2459-2474.

Filardo, G., Perdisa, F., Roffi, A., Marcacci, M., Kon, E. (2016). Stem cells in articular cartilage regeneration. J. Orthopaed. Surg. Res., 11, 42.

Friedenstein, A. J. (1976). Precursor cells of mechanocytes. Int. Rev. Cytol., 47, 327-359.

Friedenstein, A. J., Piatetzky-Shapiro, I. I., Petrakova, K. V. (1966). Osteogenesis in transplants of bone marrow cells. J. Embryol. Experim. Morphol., 16 (3), 381-390.

Gobbi, A., Karnatzikos, G., Sankineani, S. R. (2014). One-step surgery with multipotent stem cells for the treatment of large full-thickness chondral defects of the knee. Amer. J. Sports Med., 42 (3), 648-657.

Gobbi, A., Whyte, G. P. (2016). One-stage cartilage repair using a hyaluronic acid-based scaffold with activated bone marrow-derived mesenchymal stem cells compared with microfracture. Amer. J. Sports Med., 44 (11), 2846-2854, 
Gupta, P. K., Das, A. K., Chullikana, A., Majumdar, A. S. (2012). Mesenchymal stem cells for cartilage repair in osteoarthritis. Stem Cell Res. Ther., 3 (4), 25.

Hunter, D. J. (2015). Viscosupplementation for osteoarthritis of the knee. New Engl. J. Med., 372 (11), 1040-1047.

Jo, C. H., Lee, Y. G., Shin, W. H., Kim, H., Chai, J. W., Jeong, E. C., Kim, J. E., Shim, H., Shin, J. S., Shin, I. S., Ra, J. C., Oh, S., Yoon, K. S. (2014). Intra-articular injection of mesenchymal stem cells for the treatment of osteoarthritis of the knee: A proof-of-concept clinical trial. Stem Cells, 32 (5), 1254-1266.

Insall, J. N., Dorr, L. D., Scott, R. D., Scott, W. N. (1989). Rationale of the Knee Society Clinical Rating System. Clin. Orthop. Relat. Res., 248 (248), 13-14.

Kim, J.-D., Lee, G. W., Jung, G. H., Kim, C. K., Kim, T., Park, J. H., Cha, S. S., You, Y.-B. (2014). Clinical outcome of autologous bone marrow aspirates concentrate (BMAC) injection in degenerative arthritis of the knee. Eur. J. Orthopaed. Surg. Traumatol. Orthop. Traumatol., 24 (8), 1505-1511.

Koh, Y.-G., Jo, S.-B., Kwon, O.-R., Suh, D.-S., Lee, S.-W., Park, S.-H., Choi, Y.-J. (2013). Mesenchymal stem cell injections improve symptoms of knee osteoarthritis. Arthroscopy: J. Arthrosc. Rel. Surg., 29 (4), $748-755$.

Kon, E., Filardo, G., Drobnic, M., Madry, H., Jelic, M., Dijk, N. van, Della Villa, S. (2012). Non-surgical management of early knee osteoarthritis. Knee Surg. Sports Traumatol. Arthrosc., 20 (3), 436-449.

Lee, S., Nardo, L., Kumar, D., Wyatt, C. R., Souza, R. B., Lynch, J., McCulloch, C. E., Majumdar, S., Lane, N. E., Link, T. M. (2015). Scoring hip osteoarthritis with MRI (SHOMRI): A whole joint osteoarthritis evaluation system. J. Magn. Res. Imag., 41(6), 1549-1557.

McAlindon, T. E., Bannuru, R. R., Sullivan, M. C., Arden, N. K., Berenbaum, F., Bierma-Zeinstra, S. M., Hawker, G. A., Henrotin, Y., Hunter, D. J., Kawaguchi, H., Kwoh, K., Lohmander, S., Rannou, F., Roos, E. M., Underwood, M. (2014). OARSI guidelines for the non-surgical management of knee osteoarthritis. Osteoarthr. Cartil., 22 (3), 363-388.

Nakamura, N., Hui, J., Koizumi, K., Yasui, Y., Nishii, T., Lad, D., Karnatzikos, G., Gobbi, A. (2014). Stem cell therapy in cartilage repair-culture-free and cell culture-based methods. Scopus, 50 (2), 516-525.

Oliver, K. S., Bayes, M., Crane, D., Pathikonda, C. (2015). Clinical outcome of bone marrow concentrate in knee osteoarthritis. J. Prolother., 7, 937-946.

Peterfy, C. G., Guermazi, A., Zaim, S., Tirman, P. F. J., Miaux, Y., White, D., Kothari, M., Lu, Y., Fye, K., Zhao, S., Genant, H. K. (2004). Whole-organ magnetic resonance imaging score (WORMS) of the knee in osteoarthritis. Osteoarthr. Cartil., 12 (3), 177-190.

Roos, E. M., Lohmander, L. S. (2003). The knee injury and osteoarthritis outcome score (KOOS): From joint injury to osteoarthritis. Health Qual. Life Outcomes, 1, 64.

Roos, E. M., Roos, H. P., Lohmander, L. S., Ekdahl, C., Beynnon, B. D. (1998). Knee Injury and Osteoarthritis Outcome Score (KOOS) - development of a self-administered outcome measure. J. Orthopaed. Sports Phys. Ther., 28 (2), 88-96.

Tiel, J. van, Kotek, G., Reijman, M., Bos, P. K., Bron, E. E., Klein, S., Nasserinejad, K., Osch, G. J. V. M. van, Verhaar, J. A. N., Krestin, G. P., Weinans, H., Oei, E. H. G. (2016). Is T1ń mapping an alternative to delayed gadolinium-enhanced MR imaging of cartilage in the assessment of sulphated glycosaminoglycan content in human osteoarthritic knees? An in vivo validation study. Radiology, 279 (2), 523-531.

\section{JAUNAS IESPĒJAS CEL̨A LOCĪTAVAS OSTEOARTRĪTA ĀRSTĒŠANĀ, IZMANTOJOT AUTOLOGAS SARKANO KAULA SMADZEN,U MONONUKLEĀRĀS ŠŪNAS}

Pētījumā izvērtētas ceḷa locîtavas osteoartrīta klīnisko simptomu un audu struktūru izmaiņas pēc ārstēšanas ar sarkano kaula smadzeṇu mononukleāro šūnu intrartikulāru injekciju. Ceḷa locītavas II-III pakāpes osteoartrīta 32 pacientu grupai 34 ceḷa locītavās tika ievadīta mononukleāro šūnu suspensija (MNŠ). Klīniskie rezultāti 12 mēnešu apsekošanas periodā tika izvērtēti pēc Ceḷa osteoartrīta iznākuma un Ceḷa apvienības novērtējuma skalām. Locītavas audu struktūras izmaiṇu novērtējumam tika izmantotas digitālās rentgenogrammas un magnētiskās rezonanses metodes. Tika veikts klīnisko rezultātu salīdzinājums ar 28 kontroles grupas pacientiem kas tika ārstēti ar jau iepriekš praksē lietoto metodi -3 hialuronskābes (HA) injekcijas ar nedēḷas starplaiku. Salīdzinot abas grupas, statistiski nozīmīgas $(p<$ 0,05) atšķirības tika novērotas KOOS skalas sāpju sadaḷā, kā arī vairumā no skalu apakšsadaḷām tika konstatēts MNŠ grupas pārākums osteoartrīta simptomu mazināšanā. Klīniski nozīmīgas blaknes abās grupās netika reǵistrētas. Pēc MNŠ ievadīšanas minimāli klīniski nozīmīgais uzlabojums saglabājās 12 mēnešus 65\% pacientu no MNŠ grupas. Magnētiskās rezonanses izmeklējumos, 6 līdz 7 mēnešus pēc injekcijas izvērtējot pēc Visa orgāna magnētiskās rezonanses izmeklējuma punktu skalas, tika konstatētas izmaiņas no 44,31 uz 42,93 ( $p<$ $0,05)$, kas norāda uz locītavas struktūru deǵeneratīvo izmainu mazināšanos. Mononukleāro šūnu terapija 12 mēnešu periodā ievērojami samazina osteoartrīta simptomus cẹ̣a locītavā un palēnina audu deǵeneratīvo izmaiņu veidošanos. 